\title{
CLINICOPATHOLOGICAL PROFILE OF LUNG CANCER IN A TERTIARY MEDICAL CENTRE IN TRIPURA, A NORTH-EAST STATE
}

\author{
Anjan Das ${ }^{1}$, Anishim Rokhum², Kumarjit Sinha ${ }^{3}$ \\ ${ }^{1}$ Associate Professor, Department of Respiratory Medicine, Agartala Government Medical College, Agartala. \\ ${ }^{2}$ Assistant Professor, Department of Respiratory Medicine, Agartala Government Medical College, Agartala. \\ ${ }^{3}$ Senior Resident, Department of Respiratory Medicine, Agartala Government Medical College, Agartala.
}

ABSTRACT
BACKGROUND
Lung cancer is presently the most common malignant disease and is the leading cause of cancer deaths in the world. An increase in
incidence of lung cancer has been observed in India. The relative frequency and clinicopathological profile of different histological
subtypes of lung cancer have shown marked regional and geographical variation.
The aim of this study was to evaluate the clinicopathological profile of lung cancer in patients of Tripura, India.

\section{MATERIALS AND METHODS}

This prospective study was conducted over a period of 4 years, in patients with clinically and radiologically suspected lung cancer, who attended our hospital from March, 2012 to February, 2016.

\section{RESULTS}

Out of 295 patients, 239 were male, 56 were female; $69.49 \%$ of patients were between 51 to 70 years, and $85.42 \%$ patients were smokers. The most common presenting symptom was cough (74.24\%) followed by chest pain (66.78\%). Mass lesion (43.39\%) was the most common radiological presentation followed by pleural effusion (26.44\%). The commonest mode of diagnosis was imageguided FNAC; confirmed diagnosis in $54.58 \%$ patients. The most common histopathological type was squamous cell carcinoma $(40.00 \%)$ followed by adenocarcinoma (34.58\%). Almost $75 \%$ patients were diagnosed at advanced stage of disease.

\section{CONCLUSION}

It was found that lung cancer, a disease of elderly people, predominantly affects the male with smoking still remains a major risk factor. CT-guided FNAC is an important diagnostic tool. Squamous cell carcinoma was the most common histopathological type. Majority of the patients were unaware about the ill effects of smoking.

\section{KEYWORDS}

Lung Cancer, Smoking, CT Thorax, Bronchoscopy, FNAC.

HOW TO CITE THIS ARTICLE: Das A, Rokhum A, Sinha K. Clinicopathological profile of lung cancer in a tertiary medical centre in Tripura, a north-east state. J. Evolution Med. Dent. Sci. 2017;6(16):1260-1263, DOI: 10.14260/Jemds/2017/274

\section{BACKGROUND}

Lung cancer is one of the most common malignant neoplasm worldwide, accounting for more deaths than any other cancer cause. Although it was considered to be uncommon at the beginning of the centuries, it has reached epidemic proportion and is currently the leading cause of cancer related deaths in the western countries and is rising in alarming rates in developing countries. ${ }^{1}$ In 2008 , the most commonly diagnosed cancers worldwide were lung cancers (1.61 million, $12.7 \%$ of the total) and is the leading (1.38 million, $18.2 \%$ of the total) cause of cancer related death. ${ }^{2}$ In India, lung cancer was initially thought to be extremely rare. Banker in 1957 reported that lung cancer constituted 14.4\% of all cancers in a review of 9210 consecutive autopsies. ${ }^{3}$

Financial or Other, Competing Interest: None.

Submission 18-01-2017, Peer Review 12-01-2017,

Acceptance 17-02-2017, Published 23-02-2017.

Corresponding Author:

Dr. Anjan Das,

Associate Professor,

Department of Respiratory Medicine,

Agartala Government Medical College,

Agartala, Tripura, India.

E-mail:dranjan_gb@yahoo.co.in

DOI: $10.14260 /$ jemds $/ 2017 / 274$
The National Cancer Registry Programme of ICMR, in 1989, reported that cancer of trachea, bronchus and lung was the most common type of malignancy in males from Bombay, Delhi and Bhopal and was the second most common in Madras and third in Bangalore and was most unusual in Barshi, a rural area. ${ }^{4}$ The Global burden of cancer continues to increase largely because of ageing and growth of the world population along with increasing adoption of risk behaviours, particularly smoking. Tobacco smoking is the most important modifiable risk factor for lung cancer. More than $80 \%$ of the lung cancers develop in smokers. 5 There are two broad categories of lung cancer; Small cell lung cancer (SCLC) and Non-small cell lung cancer (NSCLC). NSCLC accounts for about $85 \%$ of lung cancer cases and SCLC accounts for remaining $15 \%$. NSCLC is further divided into three major pathologic subtypes: Squamous cell carcinoma, Adenocarcinoma and Large cell carcinoma. ${ }^{6}$ Despite advances in surgical techniques and combined therapies, lung cancer remains a disease with a dismal prognosis and overall 5-year survival has remained relatively unchanged at $12-16 \%$ over the past 30 years. ${ }^{7}$ This study was designed to evaluate the clinico-pathological profile of lung cancer in patients with clinical and radiological suspicion of lung cancer, attended in the Department of Respiratory Medicine (OPD/or IPD), AGMC \& GBP Hospital, Agartala, Tripura. 


\section{MATERIALS AND METHODS}

The present prospective study was conducted over a period of 4 years (from March, 2012 to February, 2016) on patients $(n=327)$ with a high Clinical and/or Radiological suspicion of lung malignancy, attended in the Department of Respiratory Medicine (OPD and/or IPD), AGMC \& GBP Hospital. Of these, 295 patients diagnosed with lung cancer were included in the study.

Patients with malignant metastases in lung from other sites, primary mediastinal masses, primary pleural malignancy and those cases of lung cancer diagnosed elsewhere and those already under treatment were excluded from study. Written informed consent was taken from all patients. A detailed medical history of the patients regarding their clinical symptoms, past medical or surgical history and personal history was taken. Thorough clinical examination was done for all patients. The cases of suspected lung cancer were then subjected to the routine laboratory and radiological investigations. Computed tomography (CT) of the chest and upper abdomen, including adrenal glands was done in 224 patients; and computed tomography (CT) of the brain was done in 25 patients. In all patients with pleural effusion, fluid was aspirated and sent for analysis, and pleural biopsy was done in 18 of these patients. Fibreoptic bronchoscopy under local anaesthesia was performed in 196 (66.44\%) Patients. Whole tracheobronchial tree was examined and wherever possible either bronchoalveolar lavage (BAL) or bronchial brushing, and Transbronchial needle aspiration (TBNA) and/or biopsy from endobronchial lesions $(n=58)$ were collected and sent to pathology for cytological and histopathological examination. TBNA from extraluminal lesion (mass/lymph node) was performed in 10 patients. CTguided FNAC was done in 215 (72.88\%) patients with pulmonary lesions (such as mass, cavity, SPN). Further investigations such as unguided FNAC was done in 52 patients with peripheral mass. FNAC of lymph nodes were performed, wherever indicated.

\section{RESULTS}

Initially, a total of 327 patients were selected for the study. Diagnosis other than lung cancer in 18 patients were excluded from the study group; and attendants of 14 patients were unwilling for further evaluation after being told about the suspicion of malignancy. Finally, a total of 295 patients were included in the study. Out of 295 patients, 239 were male and 56 were female. Male to female ratio was 4.27: 1 . The mean age of the patients was 60.46 years. Only 7 cases were up to the age of 40 years, and youngest being 21 years old. Majority of the cases (205) were between 51 to 70 years and remaining 53 cases were 71 years and above (Table-1).

\begin{tabular}{|c|c|c|}
\hline Gender & No. of Patients & Percentage (\%) \\
\hline Male & 239 & $81.02 \%$ \\
\hline Female & 56 & $18.98 \%$ \\
\hline \multicolumn{3}{|c|}{ Age Group } \\
\hline 20 to 30 years & 01 & $0.34 \%$ \\
\hline 31 to 40 years & 06 & $2.03 \%$ \\
\hline 41 to 50 years & 30 & $10.17 \%$ \\
\hline 51 to 60 years & 90 & $30.51 \%$ \\
\hline 61 to 70 years & 115 & $38.98 \%$ \\
\hline $\begin{array}{c}\text { 71 years \& } \\
\text { above }\end{array}$ & 53 & $17.97 \%$ \\
\hline \multicolumn{2}{|c|}{ Table 1. Demographic Profile of patients included } \\
in the Study (n =295) \\
\hline
\end{tabular}

$252(85.42 \%)$ patients were smokers and 43 (14.58\%) were non-smokers; majority (66.44\%) smoked bidi. The smoker to non-smoker ratio was 5.86: 1 . Significant smoking history of $\geq 20$ pack-years was present in 148 (50.17\%) cases. Among female patients, 15 gave a history of exposure to passive smoking. $18(8.03 \%)$ out of 295 patients were initially misdiagnosed as pulmonary tuberculosis. Most common presenting symptom was cough $(n=219)$, followed by chest pain $(n=197)$, dyspnoea- $(n=165)$, haemoptysis $(n=146)$, decreased appetite and weight loss $(n=106)$, fever $(n=82)$, and hoarseness of voice $(n=58)$, etc. (Table-2).

\begin{tabular}{|c|c|c|}
\hline Symptoms & No. of Patients & Percentage (\%) \\
\hline Cough & 219 & $74.24 \%$ \\
\hline Chest pain & 197 & $66.78 \%$ \\
\hline Dyspnoea & 165 & $55.93 \%$ \\
\hline Haemoptysis & 146 & $49.49 \%$ \\
\hline $\begin{array}{l}\text { Decreased appetite } \\
\text { and weight loss }\end{array}$ & 106 & $35.93 \%$ \\
\hline Fever & 82 & $27.80 \%$ \\
\hline Hoarseness of voice & 58 & $19.66 \%$ \\
\hline SVC obstruction & 32 & $10.85 \%$ \\
\hline Weakness & 28 & $9.49 \%$ \\
\hline $\begin{array}{l}\text { Headache and/or } \\
\text { convulsion }\end{array}$ & 10 & $3.39 \%$ \\
\hline Dysphagia & 6 & $2.03 \%$ \\
\hline Horner's syndrome & 4 & $1.35 \%$ \\
\hline \multicolumn{3}{|c|}{ Table 2. Clinical Presentation ( $n=295$ ) } \\
\hline
\end{tabular}

Out of 32 patients with superior vena cava (SVC) obstruction, cases of small cell carcinoma were 18, Squamous- cell carcinoma were 10 and Adenocarcinoma were 4. Average duration of symptom in our study was 4.5 months. Pancoast tumour was diagnosed in 8 (2.71\%) cases, all of whom were later found to have squamous cell carcinoma. Mass lesion $(\mathrm{n}=128)$ was the most common radiological presentation followed by pleural effusion$(n=78)$, collapse-consolidation $(n=60)$, cavitary lesion $(n=19)$ and solitary pulmonary nodule $(\mathrm{n}=12)$. Right lung was more involved (Table- 3 ).

\begin{tabular}{|c|c|c|}
\hline Site & No. of Patients & Percentage (\%) \\
\hline Mass & 128 & $43.39 \%$ \\
\hline Pleural effusion & 78 & $26.44 \%$ \\
\hline $\begin{array}{c}\text { Collapse- } \\
\text { consolidation }\end{array}$ & 60 & $20.34 \%$ \\
\hline Cavity & 17 & $5.76 \%$ \\
\hline $\begin{array}{c}\text { Solitary pulmonary } \\
\text { nodule }\end{array}$ & 12 & $4.07 \%$ \\
\hline Right lung & 162 & $54.91 \%$ \\
\hline Left lung & 115 & $38.98 \%$ \\
\hline Bilateral & 18 & $6.10 \%$ \\
\hline Table 3. Commonest Radiological Presentation \\
\hline
\end{tabular}

Local infiltration to the mediastinal structures (one or more) was found in 56(18.98\%) patients. Bony erosion of ribs and/or vertebra was present in 26 (8.81\%) cases. Extrathoracic Metastases to the liver was found in 45 $(15.25 \%)$ cases while adrenal gland in $24(8.13 \%)$ and brain in $10(3.39 \%)$ cases. Pleural biopsy confirmed diagnosis in 10 cases; malignant cell was found in pleural fluid of 11 cases. Out of 78 patients with pleural effusion, 48 had adenocarcinoma $(\mathrm{n}=48)$ followed by squamous cellcarcinoma $(n=22)$, small cell carcinoma $(n=6)$ and large cell carcinoma $(n=2)$. 
Bronchoscopy was performed in 196 patients. Most common findings were normal airways $(n=80)$, followed by intrabronchial growth $(n=58)$ associated with airway obstruction (partial/complete); and vocal cord palsy was found in 45 cases (Table- 4).

\begin{tabular}{|c|c|c|}
\hline Findings & No. of Patients & Percentage (\%) \\
\hline Vocal cord palsy & 45 & $22.96 \%$ \\
\hline Normal & 80 & $40.82 \%$ \\
\hline Wide main carina & 14 & $7.14 \%$ \\
\hline $\begin{array}{c}\text { Compression of airway } \\
\text { wall }\end{array}$ & 20 & $10.20 \%$ \\
\hline Unhealthy mucosa & 24 & $12.24 \%$ \\
\hline Intrabronchial growth & 58 & $29.59 \%$ \\
\hline \multicolumn{2}{|r|}{ Table 4. Bronchoscopy Findings (n =196) } \\
\hline
\end{tabular}

Malignant cell was found in BAL fluid (4 cases) and bronchial brushing specimens (7 cases). TBNA and biopsy, alone/combination confirmed diagnosis in $25(8.47 \%)$ endobronchial lesions, with an accuracy of $43.10 \%$. In extraluminal lesion, TBNA confirmed lung cancer in 3 cases. CT-guided FNAC confirmed diagnosis in 161 (54.58\%) patients, with an accuracy of $74.88 \%$. Unguided FNAC confirmed diagnosis in $20(6.78 \%)$ patients. The most common histopathological type was squamous cell carcinoma $(n=118)$, followed by adenocarcinoma $(n=102)$, small cell carcinoma $(n=52)$ and large cell carcinoma $(n=19)$; and undifferentiated carcinoma was detected in 4 patients (Table5). 219 (74.24\%) patients were diagnosed in advanced stages of disease.

\begin{tabular}{|c|c|c|}
\hline Type of Lung Cancer & No. of Patients & Percentage (\%) \\
\hline Squamous cell carcinoma & 118 & $40.00 \%$ \\
\hline Adenocarcinoma & 102 & $34.58 \%$ \\
\hline Small cell carcinoma & 52 & $17.63 \%$ \\
\hline Large cell carcinoma & 19 & $6.44 \%$ \\
\hline $\begin{array}{c}\text { Undifferentiated } \\
\text { carcinoma }\end{array}$ & 4 & $1.35 \%$ \\
\hline \multicolumn{2}{|c|}{ Table 5. Histological type of Lung Cancer (n=295) } \\
\hline
\end{tabular}

\section{DISCUSSION}

The mean age of patients with lung cancer has remained relatively constant over the years. The mean age in this study was 60.46 years, which is comparable to that reported by Guleria et al, 1971 and Dey A et al, 2012. In this study, majority of the patients $(69.49 \%)$ were between 51 to 70 years, which is similar to the previous studies.(8-10) The gender distribution of lung cancer has varied in different studies, with male predominance. The sex ratio reported in various Indian studies ranged from 2.7: 1 to $6.6: 1 .(9,11-13)$ The sex ratio in our study was $4.27: 1$, with male predominance. In this study, most of the patients (85.42\%) were smokers (current/ex-smokers), and smoking was the important risk factor found in this study; findings are similar to earlier studies. ${ }^{(9,14,15)}$ In our study, Cough(74.24\%) was the most common symptom, followed by chest pain $(66.78 \%)$ as was reported in most of the previous studies. $(7,9,16,15,17)$ In this study, $18(8.03 \%)$ patients were initially misdiagnosed as Pulmonary tuberculosis. Dubey N et al, 2015 and Gupta R et al, 2015 reported that number of patients $(23.4 \%$ and $42.5 \%$ respectively) of lung malignancy were initially misdiagnosed as pulmonary tuberculosis. Mass lesion (43.39\%) was the most common radiological presentation found in the present study followed by pleural effusion (26.44\%). Some of the major Indian studies also reported similar findings. $(9,11,16,18)$ In this study, CT-guided FNAC had the highest diagnostic yield $(74.88 \%)$ leading to diagnosis in $54.58 \%$ patients, which is comparable to the reports of some other authors (Bhattacharyya SK et al, Mukherjee S et al and Dubey $\mathrm{N}$ et al) and they also reported that CT-guided FNAC had the maximum diagnostic yield. In the present study, Squamous cell carcinoma $(40.00 \%)$ was the most common histopathological type, followed by Adenocarcinoma (34.58\%), Small cell carcinoma (17.63\%), and Large cell carcinoma (6.44\%); a large number of previous studies also reported similar findings. $(9,11,16,14,19-22)$ In the present study, majority $(74.24 \%)$ of the patients were diagnosed in advanced stages, which is comparable to the study reports of previous authors. $(9,21,23)$ The incidence of lung cancer has risen. The pattern of lung cancer has been changing in the West, with increasingly being diagnosed in women and Adenocarcinoma has overtaken Squamous cell carcinoma as the commonest histopathological type. ${ }^{24}$ But in India, squamous cell carcinoma is still the most common with smoking as predominant risk factor found. $(9,11,16,14,19-22)$ In our study, Squamous cell carcinoma is the predominant histopathological type; the cause is most likely due to the fact that majority of the patients in our study are smokers. Almost three quarters of patients were diagnosed at advanced stage, which is also seen in other studies. $(9,21,23)$ This suggests an urgent need of some diagnostic modality for screening and early diagnosis of patients of lung cancer.

\section{CONCLUSION}

This study has identified smoking as the important risk factor in causation of lung cancer. People should be aware of the ill effects of smoking and importance of quitting. Our study has also found that majority of the patients were diagnosed at advanced stage, whereby only palliation can be planned. Primary lung cancer should always be suspected in a person presenting with unexplained cough for several weeks with other symptoms such as weight loss, fever with non-resolving collapse-consolidation on chest radiograph. The study indicates a need to create an awareness about lung cancer, its presenting features, risk factors and radiological pattern among general practitioners for early detection of lung cancer and also to avoid misdiagnosis, so that further mortality and morbidity can be minimised.

\section{ACKNOWLEDGEMENT}

We gratefully acknowledge Pathologists and Radiologists for their contribution in the diagnosis. We are also thankful to all the patients for their co-operation and participation in this study. The study was not funded by any person or authority.

\section{REFERENCES}

[1] Nagrath SP, Hazra DK, Lahiri B, et al. Primary carcinoma of the lung: clinicopathological study of 35 cases. Ind J Chest Dis 1970;12:15-24.

[2] Ferlay J, Shin HR, Bray F, et al. Estimates of worldwide burden of cancer in 2008: GLOBOCAN 2008. Int J Cancer 2010;127(12):2893-917. 
[3] Banker DD. J Post Grad Med 1955;1:108. Cited by Nagrath SP, Hazra DK, Lahiri B, et al. Primary carcinoma of the lung clinicopathologic study of 35 cases. Indian J Chest Dis 1970;12:15-24.

[4] National Cancer Registry Programme. Biennial Report, 1988-1989. An epidemiological study. Indian council of medical research, New Delhi. Chapter 2. Cancer incidence. p 3-42.

[5] Alberg AJ, Brock MV, Samet JM. Epidemiology of lung cancer: looking to the future. J Clin Oncol 2005;23(14):3175-85.

[6] Dela Cruz CS, Tanoue LT, Matthay RA. Epidemiology of lung cancer. $5^{\text {th }}$ edn. In: Grippi MA, Elias JA, Fishman JA, et al. (eds). Fishman's pulmonary diseases and disorders. Vol 2. New York, McGraw Hill Education 2015:1667-83.

[7] Jemal A, Bray F, Center MM, et al. Global cancer statistics. CA Cancer J Clin 2011;61(2):69-90.

[8] Suliman MI, Jibran R, Majeed MZ. Demographics of bronchogenic carcinoma patients and frequency of cell types. Gomal Journal Medical Sciences 2006;4(1):2-6.

[9] Bhattacharyya SK, Mandal A, Deoghuria D, et al. Clinico-pathological profile of lung cancer in a tertiary medical centre in India: analysis of 266 cases. J Dent Oral Hyg 2011;3(3):30-3.

[10] Mukherjee S, Bandyopadhyay G, Bhattacharya A, et al. Computed tomography guided fine needle aspiration cytology of solitary pulmonary nodules suspected to be bronchogenic carcinoma: experience of a general hospital. J Cytol 2010;27(1):8-11.

[11] Dubey N, Julka A, Varudkar HG, et al. A clinicpathological profile of primary lung cancer patients presenting in a rural medical college of central India. Panacea Journal of Medical Sciences 2015;5(3):124-9.

[12] Reddy DB, Prasanthamurthy D, Satyavathi S. Bronchogenic carcinoma-a clinico-pathological study. Ind J Chest Dis 1972;14(2):86-9.

[13] Pandhi N, Malhotra B, Kajal N, et al. Clinicopathological profile of patients with lung cancer visiting chest and TB hospital, Amritsar. Sch J Med Sci 2015;3(20):802-9.
[14] Shetty CM, Lakhkar BN, Gangadhar VSS, et al. Changing pattern of bronchogenic carcinoma: a statistical variation or a reality? Chest 2005;15(2):233-8.

[15] Yogeesha KS, Vijayamahantesh NN, Sannegowda RB, et al. Clinical presentation of lung cancer in adults: a retrospective study of 61 patients from a tertiary care centre in South India. International Journal of Basic and Applied Medical Sciences 2014;4(1):195-7.

[16] Agarwala A, Roy PP, Sarkar SK, et al. Clinicopathological profile of diagnosed patients of lung cancer with its relation to smoking habit and education status in a medical college of Paschim Medinipur, West Bengal, India-a tribal area prospective. Asian Pac J Health Sci 2014;1(4):479-85.

[17] Jindal SK, Behera D. Clinical spectrum of primary lung cancer-review of Chandigarh experience of 10 years. Lung India 1990;8(2):94-8.

[18] Behera D, Balamugesh T. Lung cancer in India. Indian J Chest Dis Allied Sci 2004;46(4):269-81.

[19] Jindal SK, Malik SK, Dhand R, et al. Bronchogenic carcinoma in Northern India. Thorax 1982;37(5):3437.

[20] Ernam D, Atalay F, Atikcan S. A retrospective evaluation of 571 lung carcinoma patients. Turkish Respiratory Journal 2003;4(2):67-9.

[21] Rawat J, Sindwani G, Gaur D, et al. Clinico-pathological profile of lung cancer in Uttarakhand. Lung India 2009;26(3):74-6.

[22] Mandal SK, Singh TT, Sharma TD, et al. Clinicopathology of lung cancer in a regional cancer centre in north-eastern India. Asian Pac J Cancer Prev 2013;14(12):7277-81.

[23] Bhadke BB, Rathod RK, Deshmukh DG, et al. Clinical profile of lung cancer in rural medical college of Maharashtra (India): a prospective study of three years. Int J Med Res Rev 2016;4(6):1063-71.

[24] Quinn D, Gianlupi A, Broste S. The changing radiographic presentation of bronchogenic carcinoma with reference to cell types. Chest 1996;110(6): 1474-9. 